\title{
EFEKTIVITAS PEMBELAJARAN GEOGRAFI DI SMA DENGAN MENGGUNAKAN TEAMS
}

\author{
Merlina Malau ${ }^{1}$, Muh Zid ${ }^{2}$, Ahman Sya ${ }^{3}$ \\ ${ }^{1}$ Faculty of Social Science, Universitas Negeri Jakarta, DKI Jakarta, Indonesia \\ ${ }^{2}$ Faculty of Social Science, Universitas Negeri Jakarta, DKI Jakarta, Indonesia \\ ${ }^{3}$ Faculty of Social Science, Universitas Negeri Jakarta, DKI Jakarta Indonesia \\ merlinamalau_1412821002@mhs.unj.ac.id ${ }^{1}$, mzid@unj.ac.id ${ }^{2}$
}

\begin{abstract}
ABSTRAK
Menurut UU Sisdiknas No 20 tahun 2003, Pendidikan merupakan usaha yang sadar dan terencana untuk mewujudkan suasana belajar dan proses pembelajaran agar peserta didik secara aktif mengembangkan potensi dirinya untuk memiliki kekuatan spiritual keagamaan yang diperlukan dirinnya dan masyarakat. Pendidikan geografi yang merupakan mother of Science yaitu ilmu untuk menunjang kehidupan sepanjang hayat dan mendorong peningkatan kehidupan. Proses pelajaran geografi yang berlangsung di SMA kebanyakan masih menggunakan media terbatas pada buku teks, buku pelajaran globe peta dan lembar kegiatan siswa. dengan perkembangan informasi teknologi yang terbatas ruang dan waktu dalam bidang pendidikan titik diharap pembelajaran geografi di sekolah lebih menarik dan disukai oleh peserta didik. Oleh sebab itu fokus kajian dari penelitian ini adalah efektivitas pembelajaran geografi di SMA dengan menggunakan Microsoft teams dengan menggunakan metode penelitian deskriptif dan teknik pengumpulan data dengan kuesioner. Jumlah responden atau partisipan dalam penelitian ini yaitu 145 peserta didik yang berada di kelas X, XI dan XII IPS. Hasil penelitian ini memperlihatkan bahwa penggunaan tips dan pembelajaran geografi sangat menarik dan membantu saat mengikuti pembelajaran geografi. Hal ini dikarenakan satu aplikasi bisa digunakan untuk pengumpulan tugas, video conference, penggunaannya yang mudah sehingga pekerjaan lebih cepat selesai, terintegrasi dengan planner, dapat digunakan dimanapun dan kapanpun, serta bisa customize judul chat
\end{abstract}

Kata kunci : geografi, peserta didik, teams

\section{PENDAHULUAN}

Pembelajaran adalah suatu proses dimana siswa dan pendidik berinteraksi dengan berbagai sumber belajar dalam suatu lingkungan belajar. Menurut aliran perilaku Hamdani, belajar adalah usaha guru untuk membentuk perilaku yang diinginkan dengan menyediakan lingkungan atau stimulus. Selain itu, menurut Gagne dkk dalam Warsita, belajar adalah suatu sistem yang dirancang untuk membantu siswa dalam proses belajar, yang berisi rangkaian pengaturan yang dirancang untuk mempengaruhi dan mendukung peristiwa internal. Menurut Dimyati dan Mudjiono dalam buku Sagala, pembelajaran adalah kegiatan yang diprogramkan

Al Qalam: Jurnal Ilmiah Keagamaan dan Kemasyarakatan Vol. 16, No. 1 Januari - Juni 2022 
Merlina Malau, Muh Zid, Ahman Sya : Efektivitas Pembelajaran Geografi di SMA Dengan Menggunakan Teams

guru dalam desain pembelajaran untuk pembelajaran aktif yang menekankan pada penyediaan sumber belajar.

Lebih lanjut Warsita menjelaskan bahwa ada lima prinsip yang menjadi landasan pengertian pembelajaran yaitu: 1) Pembelajaran sebagai usaha untuk memperoleh perubahan perilaku. Prinsip ini menyatakan bahwa ciri utama proses pembelajaran itu adalah adanya perubahan perilaku dalam diri peserta didik, 2) Hasil pembelajaran ditandai dengan perubahan perilaku secara keseluruhan. Prinsip ini mengandung makna bahwa perilaku sebagai hasil pembelajaran meliputi semua aspek perilaku dan bukan hanya satu atau dua aspek saja,

3) Pembelajaran merupakan suatu proses. Prinsip ini mengandung makna bahwa pembelajaran itu merupakan suatu aktivitas yang berkesinambungan, di dalam aktivitas itu terjadi adanya tahapantahapan aktivitas yang sistematis dan terarah. 4) Proses pembelajaran terjadi karena adanya sesuatu yang mendorong dan adanya suatu tujuan yang akan dicapai, 5) Pembelajaran merupakan bentuk pengalaman. Berdasarkan pendapat tersebut di atas maka dapat disimpulkan bahwa pembelajaran adalah suatu usaha yang dilakukan oleh pendidik dalam membelajarkan peserta didik sehingga terjadi perubahan tingkah laku ke arah yang lebih baik.

${ }^{1}$ Menurut Darsono dan Hamdani, pembelajaran memiliki ciri-ciri tersendiri, ciri-ciri dari pembelajaran yaitu; a) Pembelajaran dilakukan secara sadar dan direncanakan dengan sistematis. b) Pembelajaran dapat menumbuhkan perhatian dan motivasi siswa dalam belajar. c) Pembelajaran dapat menyediakan bahan belajar yang menarik perhatian dan menantang siswa. d) Pembelajaran dapat menggunakan alat bantu belajar yang tepat dan menarik. e) Pembelajaran dapat menciptakan suasana belajar yang aman dan menyenangkan bagi siswa f) Pembelajaran dapat membuat siswa siap menerima pelajaran, baik secara fisik maupun secara psikologi. g) Pembelajaran menekankan keaktifan siswa. h) Pembelajaran dilakukan secara sadar dan sengaja. Oleh karena itu, pembelajaran pasti mempunyai tujuan yaitu membantu siswa agar memperoleh berbagai pengalaman dan dengan pengalaman itu, tingkah laku siswa bertambah, baik kuantitas maupun kualitasnya. Tingkah laku ini meliputi pengetahuan, keterampilan dan nilai atau norma yang berfungsi pengendali sikap dan perilaku siswa.

${ }^{1}$ Arfani, L. (2016). Mengurai hakikat pendidikan, belajar dan pembelajaran. Pelita Bangsa Pelestari Pancasila, 11(2), 81-97. https://pbpp.ejournal.unri.ac.id/index.php/JPB/article/view/5160

Al Qalam: Jurnal Ilmiah Keagamaan dan Kemasyarakatan Vol. 16, No. 1 Januari - Juni 2022 
Merlina Malau, Muh Zid, Ahman Sya : Efektivitas Pembelajaran Geografi di SMA Dengan Menggunakan Teams

Di dalam pembelajaran juga terdapat komponen-komponen, dimana komponen-komponen pembelajaran merupakan suatu proses, maka dalam proses pembelajaran ada beberapa komponen yang saling berinteraksi satu dengan yang lain sehingga disebut sebagai sistem. Sebagai suatu sistem, proses belajar itu saling berkaitan dan bekerja sama untuk mencapai tujuan yang ingin dicapainya. Komponen-komponen proses pembelajaran adalah:

Pertama. Tujuan adalah suatu harapan atau cita-cita yang ingin dicapai dari pelaksanaan suatu kegiatan. Tidak ada suatu kegiatan pembelajaran yang tidak mempunyai tujuan, dan hal ini telah dipersiapkan oleh seorang guru sebelum kegiatan pembelajaran yang tertera dalam rencana pembelajaran yang dirumuskan melalui tujuan pembelajaran khusus.

Kedua bahan pembelajaran. Bahan pembelajaran merupakan substansi yang akan disajikan dalam kegiatan pembelajaran. Tanpa materi pembelajaran program pembelajaran tidak akan berjalan. Karena itu, guru yang akan mengajar harus memiliki dan menguasai materi pelajaran yang akan disampaikan kepada peserta didik.

Ketiga, pendekatan, model, strategi, metode, teknik Komponen yang ketiga ini mempunyai fungsi yang sangat menentukan. Keberhasilan pencapaian tujuan sangat ditentukan oleh komponen ini. Bagaimanapun lengkap dan jelasnya komponen lain, tanpa dapat diimplementasikan melalui strategi yang tepat, maka komponen-komponen tersebut tidak akan memiliki makna dalam proses pencapaian tujuan.

Ke empat, media pembelajaran. Media pembelajaran merupakan alat atau wahana yang digunakan guru dalam proses pembelajaran untuk membantu penyampaian pesan pembelajaran. Media pembelajaran berfungsi meningkatkan peranan strategi pembelajaran.

Ke lima, evaluasi. Evaluasi bukan saja berfungsi untuk melihat keberhasilan siswa dalam proses pembelajaran, tetapi juga berfungsi sebagai umpan balik bagi guru atas kinerjanya dalam pengelolaan pembelajaran. Melalui evaluasi kita dapat melihat kekurangan dalam pemanfaatan berbagai komponen sistem pembelajaran.

\section{Hakikat Pembelajaran Geografi}

${ }^{2}$ Pembelajaran geografi adalah geografi yang diajarkan di tingkat sekolah dasar dan sekolah menengah. Oleh karena itu, penjabaran konsep konsep, pokok bahasan, dan subpokok bahasannya harus disesuaikan dan diserasikan dengan tingkat pengalaman dan perkembangan psikologi peserta didik pada jenjang-jenjang pendidikan (Nursid Sumaatmadja, 2001: 9). Mengingat

2 Andhini N. F. (2017). Hakikat Pembelajaran Geografi. Journal of Chemical Information and Modeling, 53(9), 1689-1699.

Al Qalam: Jurnal Ilmiah Keagamaan dan Kemasyarakatan Vol. 16, No. 1 Januari - Juni 2022 
Merlina Malau, Muh Zid, Ahman Sya : Efektivitas Pembelajaran Geografi di SMA Dengan Menggunakan Teams

luasnya pengertian geografi, pakar-pakar geografi pada Seminar dan Lokakarya di Semarang tahun 1998 mendefinisikan pengertian geografi adalah ilmu yang mempelajari persamaan dan perbedaan fenomena geosfer dengan sudut pandang kelingkungan atau kewilayahan dalam konteks keruangan (Nursid Sumaatmadja, 2001: 11). Objek studi geografi tidak lain adalah geosfer yaitu permukaan bumi yang terdiri atmosfer (lapisan udara), litosfer (lapisan batuan/ kulit bumi), hidrosfer (lapisan air), dan biosfer (lapisan kehidupan). Bintarto dan Surastopo Hadisumarno (1979: 12-24) menjelaskan bahwa pendekatan yang digunakan dalam kajian geografi adalah sebagai berikut:

a. Pendekatan keruangan

yaitu perbedaan yang memepelajari perbedaan lokasi mengenai sifat-sifat penting atau seri sifatsifat penting.

b. Pendekatan kelingkungan yaitu pendekatan yang menekankan pada interaksi antara organisme hidup dengan lingkungan.

c. Pendekatan kompleks wilayah yaitu pendekatan geografi yang menekankan kombinasi antara pendekatan keruangan dan pendekatan kelingkungan. Nursid Sumaatmadja (2001: 12) menyatakan bahwa pembelajaran geografi hakikatnya adalah pembelajaran tentang aspek-aspek keruangan permukaan bumi yang merupakan keseluruhan gejala alam dan kehidupan umat manusia dengan variansi kewilayahan. Oleh karena itu dapat disimpulkan bahwa pembelajaran geografi di sekolah merupakan pembelajaran tentang hakikat geografi yang meliputi aspek-aspek keruangan, kelingkungan, dan kewilyahan dengan objek studi geografi adalah geosfer yang terdiri atas atmosfer, litosfer, hidrosfer dan biosfer yang disesuaikan dengan tingkat perkembangan psikologi peserta didik pada jenjang-jenjang pendidikan. Berdasarkan Permendiknas nomor 22 tahun 2006 tentang standar isi, adanya pembelajaran geografi di sekolah bertujuan agar peserta didik memiliki kemampuan sebagai berikut. 1. Memahami pola spasial, lingkungan dan kewilayahan serta proses yang berkaitan. 2. Menguasai keterampilan dasar dalam memperoleh data dan informasi, mengkomunikasikan dan menerapkan pengetahuan geografi. 3. Menampilkan perilaku peduli terhadap lingkungan hidup dan memanfaatkan sumber daya alam secara arif serta memiliki toleransi terhadap keragaman budaya masyarakat.

Berdasarkan kutipan di atas dapat disimpulkan bahwa pembelajaran geografi pada jenjang kelas $\mathrm{X}$ bertujuan membekali peserta didik agar memahami, menerapkan, menganalisis dan mengevaluasi pengetahuan faktual, konseptual, prosedural, dan metakognitif pada tingkat teknis,

Al Qalam: Jurnal Ilmiah Keagamaan dan Kemasyarakatan Vol. 16, No. 1 Januari - Juni 2022 
Merlina Malau, Muh Zid, Ahman Sya : Efektivitas Pembelajaran Geografi di SMA Dengan Menggunakan Teams

spesifik, detil, dan kompleks berdasarkan rasa ingin tahunya tentang ilmu penge-tahuan, teknologi, seni, budaya, dan humaniora dengan wawasan kemanusiaan, kebangsaan, kenegaraan, dan peradaban terkait penyebab fenomena dan kejadian, serta menerapkan pengetahuan pada bidang kajian yang spesifik sesuai dengan bakat dan minatnya untuk memecahkan masalah

Hal ini bisa dilihat dari Standar Kompetensi (SK) dan Kompetensi Dasar (KD) mata pelajaran geografi kelas $\mathrm{X}$, sebagai berikut:

3.1 Memahami pengetahuan dasar geografi dan terapannya dalam kehidupan sehari-hari

3.2 Memahami dasar-dasar pemetaan, pengindraan jauh, dan Sistem Informasi Geografis (SIG)

3.3 Memahami langkah-langkah penelitian ilmu geografi dengan menggunakan peta

3.4 Menganalisis dinamika planet bumi sebagai ruang kehidupan

3.5 Menganalisis dinamika litosfer dan dampaknya terhadap kehidupan

3.6 Menganalisis dinamika atmosfer dan dampaknya terhadap kehidupan

3.7 Menganalisis dinamika hidrosfer dan dampaknya terhadap kehidupan

Standar Kompetensi (SK) dan Kompetensi Dasar (KD) mata pelajaran geografi kelas XI, sebagai berikut:

3.1 Memahami kondisi wilayah dan posisi strategis Indonesia sebagai poros maritim dunia

3.2 Menganalisis sebaran flora dan fauna di Indonesia dan dunia berdasarkan karakteristik ekosistem

3.3 Menganalisis sebaran dan pengelolaan sumber daya kehutanan, pertambangan, kelautan, dan pariwisata sesuai prinsip-prinsip pembangunan berkelanjutan

3.4 Menganalisis ketahanan pangan nasional, penyediaan bahan industri, serta potensi energi baru dan terbarukan di Indonesia

3.5 Menganalisis dinamika kependudukan di Indonesia untuk perencanaan pembangunan

3.6 Menganalisis keragaman budaya bangsa sebagai identitas nasional berdasarkan keunikan dan sebaran

3.7 Menganalisis keragaman budaya bangsa sebagai identitas nasional berdasarkan keunikan dan sebaran

Standar Kompetensi (SK) dan Kompetensi Dasar (KD) mata pelajaran geografi kelas XII, sebagai berikut:

3.1 Memahami konsep wilayah dan pewilayahan dalam perencanaan tata ruang wilayah nasional, provinsi, dan kabupaten/kota.

Al Qalam: Jurnal Ilmiah Keagamaan dan Kemasyarakatan Vol. 16, No. 1

Januari - Juni 2022 
Merlina Malau, Muh Zid, Ahman Sya : Efektivitas Pembelajaran Geografi di SMA Dengan Menggunakan Teams

3.2 Menganalisis struktur keruangan desa dan kota, interaksi desa dan kota, serta kaitannya dengan usaha pemerataan pembangunan

3.3 Menganalisis jaringan transportasi dan tata guna lahan dengan peta dan/atau citra pengindra-an jauh serta Sistem Informasi Geografis (SIG) kaitannya dengan pengem-bangan potensi wilayah dan kesehatan lingkungan

3.4 Menganalisis karakteristik negara maju dan negara berkembang dalam konteks pasar bebas

\section{Microsoft Teams}

Microsoft teams adalah sebuah platform komunikasi dan kolaborasi terpadu yang menggabungkan percakapan kerja, rapat video, penyimpanan berkas termasuk kolaborasi berkas dan interaksi integrasi aplikasi. ini terintegrasi dengan rangkaian produk Microsoft 365 selain itu juga dapat diintegrasikan dengan aplikasi selain buatan Microsoft. beberapa fitur tim hanya tersedia dalam paket berbayar Microsoft 365 versi berbayar dengan fitur lengkap menyertakan penyimpanan tambahan dengan paket yang menyertakan penyimpanan file mulai dari 1 tera per guna bahkan layanan ini bisa menghadirkan banyak peserta hingga 1000 orang dalam satu konferensi . Microsoft teams merupakan perangkat yang aman dan terjangkau untuk pendidikan dengan perangkat yang aman dan terjangkau, alat luar biasa untuk pendidikan dan peluang pengembangan profesional, Microsoft hadir untuk mendukung para pendidik dalam menciptakan lingkungan online inklusif yang membantu siswa belajar di manapun.

Dalam teams guru dapat dengan cepat berkomunikasi dengan siswa, berbagi file dan situs web, membuat buku catatan kelas OneNote dan mendistribusikan serta menilai tugas. buku catatan kelas warnet yang berintegrasi dan dan manajemen tugas ujung-ke-ujung kan guru untuk mengatur pelajaran interaksi dan memberikan umpan balik yang efektif dan tepat waktu. administrator dan staf sekolah dapat tetap mengetahui dan berkolaborasi menggunakan steam staf untuk pengumuman dan percakapan topikal. pendidik dapat berbagi materi pengajaran menggunakan komunitas pembelajaran profesional. tim kelas dapat digunakan untuk membuat ruang kelas collaborative, diakan tempat pertemuan virtual memfasilitasi pembelajaran dengan tugas dan umpan balik dan memimpin panggilan langsung dengan siswa.

\section{METODE PENELITIAN}

Penelitian ini menggunakan metode deskriptif. Populasi dan sampel berjumlah 40 peserta didik di kelas XII IPS angket disertai dengan wawancara. Teknik analisis yang dilakukan dengan Al Qalam: Jurnal Ilmiah Keagamaan dan Kemasyarakatan Vol. 16, No. 1

Januari - Juni 2022 
Merlina Malau, Muh Zid, Ahman Sya : Efektivitas Pembelajaran Geografi di SMA Dengan Menggunakan Teams

menggunakan persentase dan penjelasan kualitatif. Jenis data yang dikumpulkan adalah data primer dan data sekunder. Data primer diperoleh secara langsung dari hasil wawancara mendalam dengan responden. Sedangkan, data sekunder adalah data yang diperoleh dari hasil penelurusan arsip, dan dokumen maupun dari artikel-artikel yang sudah terbit di jurnal-jurnal penelitian.

Untuk menentukan responden, peneliti menggunakan teknik simple random sampling dimana pengambilan anggota sampel dari populasi dilakukan secara acak tanpa memperhatikan strata yang ada dalam populasi Dalam penelitian ini, data terkumpul di analisis menggunakan teknik kualitatif. Analisis data kualitatif disebut juga metode postpositivistik karena berlandaskan pada filsafat postpositivisme.

Dimana memandang realitas sosial sebagai sesuatu yang holistik/utuh, kompleks, dinamis, penuh makna dan hubungan gejala bersifat interaktif (Sugiyono, 2015)

\section{HASIL DAN PEMBAHASAN}

${ }^{3}$ Microsoft team adalah hubungan digital yang menyatukan percakapan, content, penugasan, dan aplikasi di satu tempat mungkinkan guru menciptakan lingkungan belajar yang dinamis. Microsoft bertujuan untuk menawarkan pengalaman belajar yang jauh Sebagai pribadi yang menarik dan tubuh secara sosial seperti belajar di kelas. Microsoft telah memungkinkan siswa dan guru dapat tetap berkomunikasi dan saling membantu menggunakan percakapan, dan dapat merasa seperti mereka bertemu langsung. Guru dapat melacak kemajuan siswa dalam pekerjaan sehari-hari mereka menggunakan tugas sama seperti di ruang kelas guru dapat menggunakan aplikasi dan fungsi tim untuk mendukung cara mereka untuk bekerja terbaik.

Dalam teams, guru dapat dengan cepat berkomunikasi dengan siswa, berinteraksi, berbagi file dan situs web membuat buku catatan kelas dan mendistribusikan serta menilai tugas. Buku catatan kelas yang terintegrasi dan manajemen tugas ujung ke ujung memungkinkan guru untuk mengatur pelajaran interaktif dan memberikan umpan balik yang yang efektif dan tepat waktu titik berat organisasi sekolah dapat tetap mengetahui dan berkolaborasi menggunakan tim staf untuk pengumuman dan percakapan topikal. Pendidik dapat berbagi materi pelajaran menggunakan

${ }^{3}$ Situmorang, A. S. (2020). Microsoft Teams for Education Sebagai Media Pembelajaran. Microsoft Teams for Education Sebagai Media Pembelajaran Interaktif Meningkatkan Minat Belajar, 02(01), 30-35.

Al Qalam: Jurnal Ilmiah Keagamaan dan Kemasyarakatan Vol. 16, No. 1 Januari - Juni 2022 
Merlina Malau, Muh Zid, Ahman Sya : Efektivitas Pembelajaran Geografi di SMA Dengan Menggunakan Teams

komunitas pembelajaran profesional. Kelas dapat digunakan untuk membuat ruang kelas kolaboratif menyediakan panggilan langsung dengan siswa. Dengan adanya Microsoft teams sangat membantu sekali guru dalam pembelajaran geografi dikarenakan fitur-fitur yang ada di Microsoft teams sudah sangat lengkap.

Adapun kelebihan-kelebihan fitur dari Microsoft teams yang bermanfaat dalam pembelajaran geografi diantaranya:

a. chat, Riwayat obrolan untuk saluran umum tetap ada, sehingga pengguna dapat menggunakan channel sebagai ringkasan yang bisa merekam berapa lama rapat berlangsung, mendokumentasikan perubahan, atau menambahkan anggota tim baru dengan cepat.

b. Panggilan audio dan video, guru dapat memanggil peserta didik jika belum hadir atau belum mengikuti kelas dalam teams

c. File, Di dalam File pengguna dapat dengan cepat menemukan dan menampilkan file di OneNote, OneDrive, dan dalam Microsoft Teams (disimpan di situs SharePoint mereka sendiri). Ada juga tab 'Terbaru' yang sangat membantu sehingga pengguna dapat dengan cepat mengakses dokumen terbaru yang sedang pengguna kerjakan, serta pintasan ke Unduhan pengguna.

d. Konektivitas ke perangkat lain

Kemampuan aplikasi Microsoft Teams untuk berintegrasi dengan perangkat lain seperti smartphone, tablet, dan kamera, bersama dengan periferal seperti speaker dan headphone.

e. Microsoft class teams

Guru dapat dengan cepat berkomunikasi dengan siswa, berbagi file dan situs web, membuat Notebook Kelas OneNote, dan mendistribusikan serta menilai tugas. Siswa bebas menggunakan aplikasi Microsoft yang paling mereka kenal, seperti:

1) Word,

2) PowerPoint,

3) OneNote, dan

4) Excel

5) Notebook Kelas OneNote yang telah terintegrasi dan manajemen tugas yang memungkinkan guru untuk mengatur pelajaran interaktif, menyampaikan pembelajaran yang dipersonalisasi, dan memberikan umpan balik yang efektif dan tepat waktu.

Untuk peserta didik sendiri penggunaan teams dalam pembelajaran geografi sangat menyenangkan karena fitur-fitur yang digunakan sudah lengkap dan juga sudah sesuai dengan pendidikan digital 4.0. dibandingkan sebelum menggunakan teams, peserta didik dulunya masih

Al Qalam: Jurnal Ilmiah Keagamaan dan Kemasyarakatan Vol. 16, No. 1

Januari - Juni 2022 
Merlina Malau, Muh Zid, Ahman Sya : Efektivitas Pembelajaran Geografi di SMA Dengan Menggunakan Teams

banyak menggunakan Learning Management Sytem yang berbeda-beda, seperti untuk pengumpulan tugas menggunakan google classroom, untuk video conference menggunakan zoom meeting. Banyaknya LMS yang digunakan dikarenakan belum terakomodirnya 1 LMS untuk banyak fitur. Hal ini menyebabkan peserta didik memiliki banyak LMS dan banyak akun yang kadang kala akhirnya peserta didik menjadi lupa akun dan password.

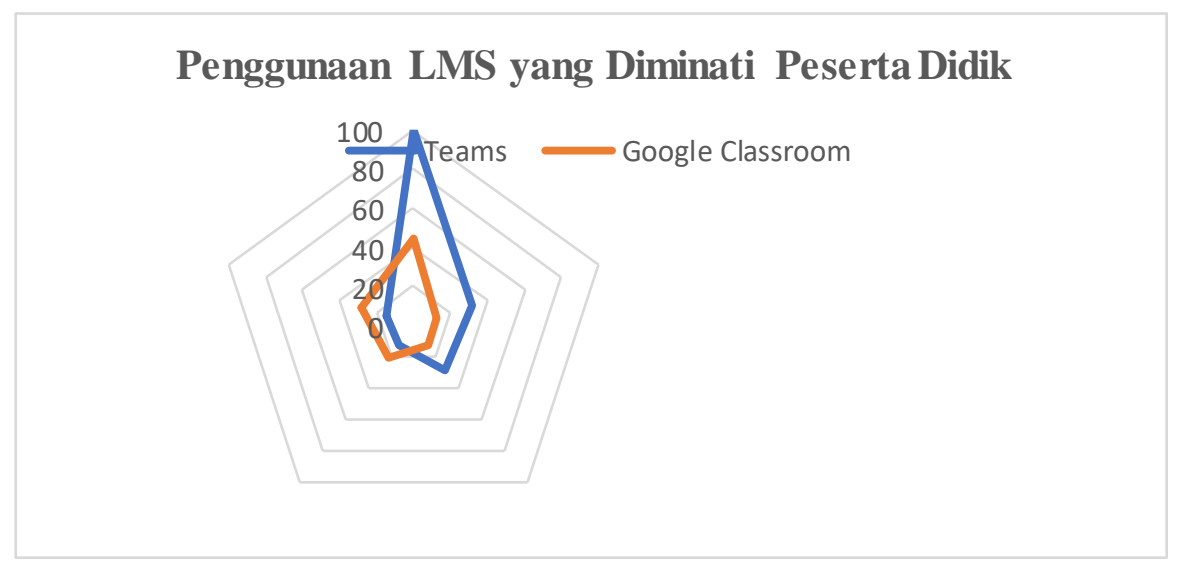

\section{KESIMPULAN}

Pembelajaran merupakan suatu proses interaksi antara peserta didik dengan pendidik dan berbagai sumber belajar yang ada di lingkungan belajar tersebut. Menurut aliran behavioristik dalam Hamdani mengatakan bahwa pembelajaran adalah usaha guru membentuk tingkah laku yang diinginkan dengan menyediakan lingkungan atau stimulus.

Pembelajaran geografi adalah geografi yang diajarkan di tingkat sekolah dasar dan sekolah menengah. Oleh karena itu, penjabaran konsep konsep, pokok bahasan, dan subpokok bahasannya harus disesuaikan dan diserasikan dengan tingkat pengalaman dan perkembangan psikologi peserta didik pada jenjang-jenjang pendidikan. Objek studi geografi tidak lain adalah geosfer yaitu permukaan bumi yang terdiri atmosfer (lapisan udara), litosfer (lapisan batuan/ kulit bumi), hidrosfer (lapisan air), dan biosfer (lapisan kehidupan).

Merebaknya virus corona 19 pada tahun 2019, yang dimana penularannya sangat cepat dan juga melanda seluruh dunia. Akhirnya mengubah semua bidang ekonomi, transportasi, dan juga pendidikan. Sistem pendidikan di seluruh dunia berubah, dengan semakin meningkatnya korban akibat virus corona 19. Pembelajaran secara tatap muka di sekolah harus diubah menjadi daring hal ini dilakukan untuk memutus mata rantai perkembangan virus corona 19.

Al Qalam: Jurnal Ilmiah Keagamaan dan Kemasyarakatan Vol. 16, No. 1 Januari - Juni 2022 
Merlina Malau, Muh Zid, Ahman Sya : Efektivitas Pembelajaran Geografi di SMA Dengan Menggunakan Teams

Dengan dilakukannya pembelajaran secara daring, maka tenaga pengajar harus bisa menemukan Learning Management System (LMS) yang sesuai dengan tingkatan yang diampu tenaga pengajar.

Saat ini sudah banyak LMS yang tersedia, seperti Google classroom, webex, zoom meeting, dan Microsoft teams. Untuk pembelajaran geografi, LMS yang mendukung adalah Microsoft teams, hal ini dikarenakan fitur yang ada pada Microsoft teams yang menarik, lengkap dan sudah sesuai dengan tuntutan zaman.

\section{DAFTAR PUSTAKA}

Andhini, N. F. (2017). Hakikat Pembelajaran Geografi. Journal of Chemical Information and Modeling, 53(9), 1689-1699.

Arfani, L. (2016). Mengurai hakikat pendidikan, belajar dan pembelajaran. Pelita Bangsa Pelestari Pancasila, 11(2), 81-97. https://pbpp.ejournal.unri.ac.id/index.php/JPB/article/view/5160

Nisa, K., Triwoelandari, R., \& Kosim, A. M. (2018). Jurnal Mitra Pendidikan ( JMP Online ) 1077-1063), $10(2$.

Situmorang, A. S. (2020). Microsoft Teams for Education Sebagai Media Pembelajaran. Microsoft Teams for Education Sebagai Media Pembelajaran Interaktif Meningkatkan Minat Belajar, 02(01), 30-35.

Al Qalam: Jurnal Ilmiah Keagamaan dan Kemasyarakatan Vol. 16, No. 1

Januari - Juni 2022 